\title{
Clinical Perspectives of Single-Cell RNA Sequencing
}

\author{
Nayoung Kim ${ }^{1,2,+}$ (D), Hye Hyeon Eum ${ }^{1,2,+}$ and Hae-Ock Lee ${ }^{1,2, *(\mathbb{D})}$ \\ 1 Department of Microbiology, College of Medicine, The Catholic University of Korea, Seoul 06591, Korea; \\ wwkd0324@gmail.com (N.K.); hheum1107@gmail.com (H.H.E.) \\ 2 Department of Biomedicine and Health Sciences, Graduate School, The Catholic University of Korea, \\ Seoul 06591, Korea \\ * Correspondence: haeocklee@catholic.ac.kr; Tel.: +82-2-2258-8155 \\ + Equal contribution.
}

check for

updates

Citation: Kim, N.; Eum, H.H.; Lee, H.-O. Clinical Perspectives of Single-Cell RNA Sequencing. Biomolecules 2021, 11, 1161. https:// doi.org/10.3390/biom11081161

Academic Editor: Alfredo Pulvirenti

Received: 15 July 2021

Accepted: 3 August 2021

Published: 6 August 2021

Publisher's Note: MDPI stays neutral with regard to jurisdictional claims in published maps and institutional affiliations.

Copyright: (c) 2021 by the authors. Licensee MDPI, Basel, Switzerland. This article is an open access article distributed under the terms and conditions of the Creative Commons Attribution (CC BY) license (https:/ / creativecommons.org/licenses/by/ $4.0 /)$.

\begin{abstract}
The ability of single-cell genomics to resolve cellular heterogeneity is highly appreciated in cancer and is being exploited for precision medicine. In the recent decade, we have witnessed the incorporation of cancer genomics into the clinical decision-making process for molecular-targeted therapies. Compared with conventional genomics, which primarily focuses on the specific and sensitive detection of the molecular targets, single-cell genomics addresses intratumoral heterogeneity and the microenvironmental components impacting the treatment response and resistance. As an exploratory tool, single-cell genomics provides an unprecedented opportunity to improve the diagnosis, monitoring, and treatment of cancer. The results obtained upon employing bulk cancer genomics indicate that single-cell genomics is at an early stage with respect to exploration of clinical relevance and requires further innovations to become a widely utilized technology in the clinic.
\end{abstract}

Keywords: single-cell genomics; single-cell RNA sequencing; treatment response; patient stratification; clinical decision

\section{Introduction}

Cells are the basic units of all living organisms. Single-cell genomics has ushered in a new era in biology by employing genomics to define cellular identity and states. Genomic data of individual cells provide the status of thousands of genes or regulatory elements simultaneously. For instance, data pertaining to the transcriptome and the epigenome (chromatin openness) can be obtained through single-cell RNA sequencing (scRNA-seq) and single-cell ATAC-seq (assay for transposase-accessible chromatin with sequencing), respectively. As cellular identity and function are closely linked to the spatial and temporal positions of cells, genomic data complement the traditional cell type definition that takes into consideration of the anatomical, morphological, and developmental traits. Massively parallel genomic analyses recapitulate dynamic cellular states and therefore, single-cell genomics provides high-resolution criteria for determining the cellular identities in health and disease conditions.

Cancer is defined as an abnormal growth of cells characterized by uncontrolled division and the ability of these cells to invade and destroy normal tissue architectures. From a genomic perspective, cancer is a disease that arises as a result of genomic instability, a phenomenon that disrupts the normal genomic program in healthy cells within the tissue context. Indeed, single-cell transcriptome analysis has demonstrated the separation of cancer cells from normal counterpart cells with the cancer cells positioned in distinct clusters in each patient while non-malignant cells show multi-patient clustering, suggesting a gross deviation from the normal genomic programs [1,2] (Figure 1A-C). The transcriptional clusters may-in part-represent specific genetic alterations or transcriptional modules associated with tumor progression, metastasis, and response, and resistance to a specific treatment [1,3-5]. In addition to the genomic characterization of tumor cells, single-cell 
genomics allows for the cellular dissection and the characterization of the tumor microenvironment, which influences tumor cell behavior and the effect of anti-cancer therapies directed at stromal and immune cells [2] (Figure 1D).

A

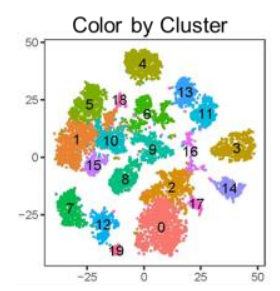

Color by Sample
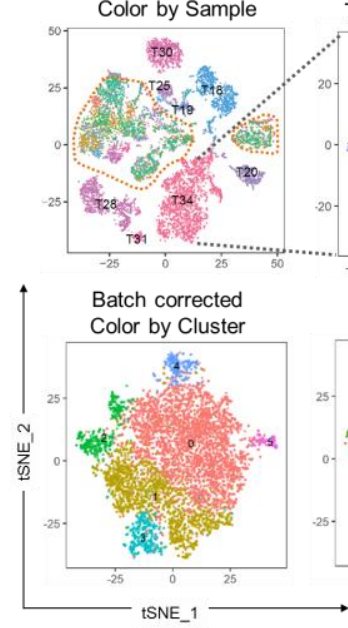

D

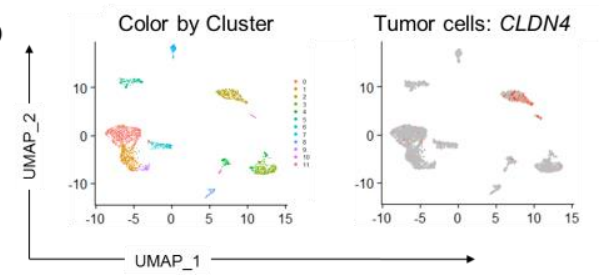

B

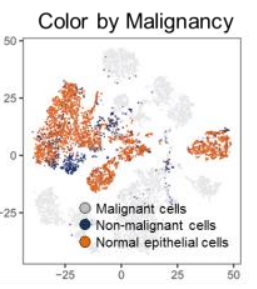

T34 Color by Cluster

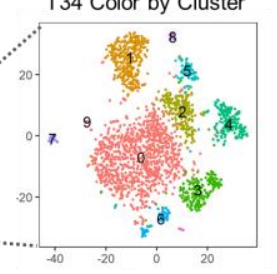

Batch corrected

Color by Sample
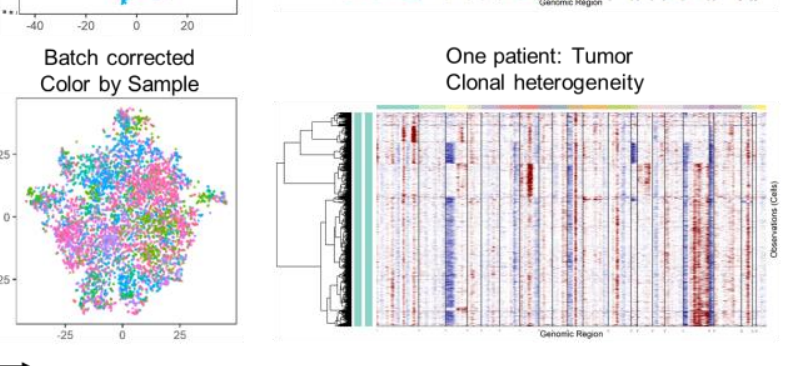

Multiple patients: Normal No CNV pattern
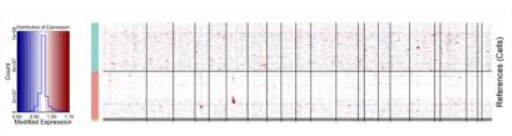

Multiple patients:Tumor Patient-specific CNV pattern

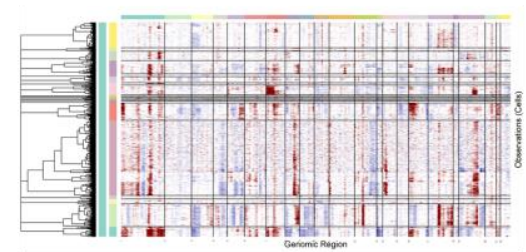

C \# somatic mutation

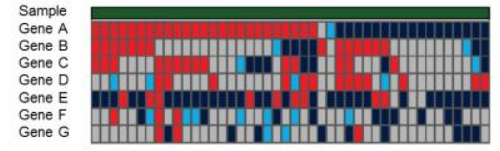

II Wild type II mutant \ undetermined
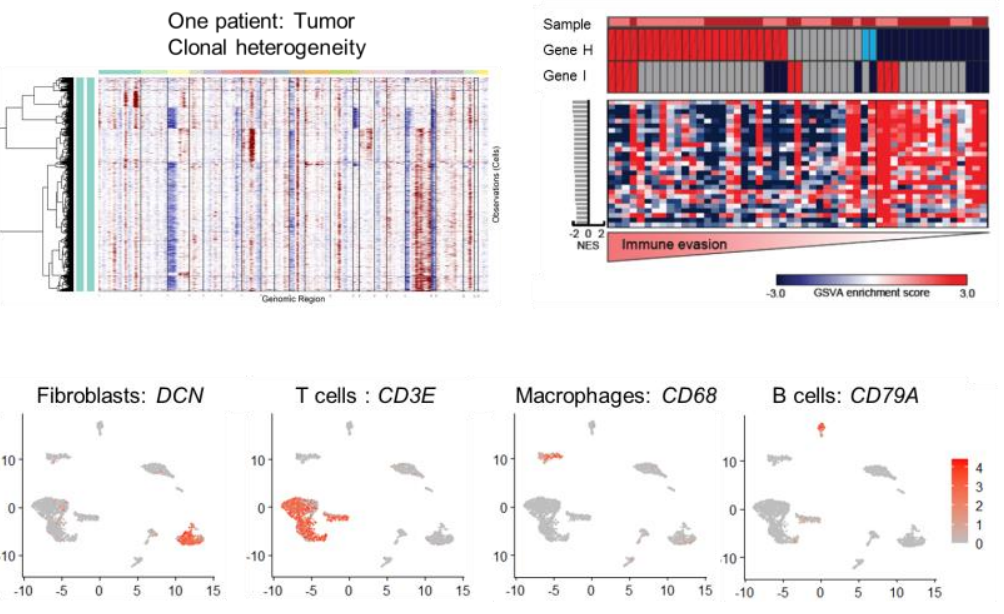

Figure 1. Cellular heterogeneity in cancer depicted by single cell transcriptome analysis. (A) Clustering analysis shows patient-specific tumor groups in multiple samples (Color by Sample) compared to the multi-patient clustering of normal and non-malignant cells (orange dotted outline). Intratumoral heterogeneity in a selected patient sample is depicted in T34 Color by Cluster. Batch correction by multi-set canonical correlation analysis (CCA) [6] clears the inter-patient cluster variation originating from both technical and biological sources (batch corrected tumor cell clusters: Color by Cluster and Color by Sample). (B) Copy number inference from gene expression data shows patient-specific patterns for tumor cells and intratumoral heterogeneity within a selected patient sample. (C) Somatic mutation calls separate a tumor cell cluster (upper UMAP) and demonstrate intratumoral heterogeneity in individual cells (lower heatmaps). (D) Diverse stromal and immune cell types in the tumor microenvironment. Plots are arbitrarily generated to demonstrate the depicted features.

In clinical practice, the benefits associated with the implementation of single-cell resolution cancer genomics are uncertain. Here, we will review the clinical implementation of conventional cancer genomics and examine clinical cases and areas that are addressed by single-cell genomics, and then discuss whether and how this technology will promote the development of better strategies to diagnose, monitor, and treat cancer.

\section{Brief Overview of Cancer Genomics in Precision Oncology}

There were quite some hurdles to utilizing cancer genome data to make clinical decisions regarding the treatment choices. Molecular target discoveries that aid platform development for clinical implementation would enable us to obtain a better understanding whether and how the single-cell genomics data can be incorporated into the clinical decision-making process (Table 1 ). 
Table 1. Cancer genomics implemented in the clinical decision process.

\begin{tabular}{|c|c|c|c|}
\hline $\begin{array}{l}\text { Genomic Features } \\
\text { Purpose }\end{array}$ & $\begin{array}{l}\text { Representative Test } \\
\text { Target Tumor }\end{array}$ & $\begin{array}{l}\text { Test Platform } \\
\text { Coverage }\end{array}$ & Diagnostic Use \\
\hline \multirow{3}{*}{$\begin{array}{l}\text { Genomic DNA (+RNA in } \\
\text { Oncomine Dx): DNA point } \\
\text { mutations, gene amplification, } \\
\text { translocation, TMB, HRD } \\
\text { Molecular targeted therapy } \\
\text { Response prediction }\end{array}$} & $\begin{array}{c}\text { FoundationOne CDx Solid } \\
\text { tumors }\end{array}$ & \multirow{3}{*}{$\begin{array}{c}\text { NGS panel } \\
\text { 324 genes } \\
\text { NGS panel } \\
23 \text { genes from DNA and fusions in } \\
\text { ROS1 and RET from RNA } \\
\text { NGS panel }\end{array}$} & $\begin{array}{c}\text { FDA approved } \\
16 \text { CDx indications }\end{array}$ \\
\hline & $\begin{array}{l}\text { Oncomine Dx } \\
\text { NSCLC }\end{array}$ & & $\begin{array}{c}\text { FDA approved } \\
4 \text { genes CDx in NSCLC }\end{array}$ \\
\hline & $\begin{array}{l}\text { MSK-IMPACT } \\
\text { Solid tumors }\end{array}$ & & $\begin{array}{l}\text { FDA approved } \\
\text { No indication }\end{array}$ \\
\hline \multirow[t]{4}{*}{$\begin{array}{l}\text { RNA Gene expression } \\
\text { Prognostic } \\
\text { Predictive }\end{array}$} & $\begin{array}{c}\text { Mammaprint Breast cancer } \\
\text { Prosigna (Pam50) Breast cancer }\end{array}$ & $\begin{array}{c}\text { Microarray } \\
70 \text { genes } \\
\text { NanoString nCounter } \\
58 \text { genes }\end{array}$ & $\begin{array}{l}\text { FDA approved } \\
\text { NCCN guidelines } \\
\text { FDA approved } \\
\text { NCCN guidelines }\end{array}$ \\
\hline & Oncotype Dx Breast cancer & $\begin{array}{l}\text { RT-PCR } \\
21 \text { genes }\end{array}$ & NCCN guidelines \\
\hline & $\begin{array}{l}\text { Breast Cancer Index } \\
\text { Breast cancer }\end{array}$ & $\begin{array}{l}\text { RT-PCR } \\
7 \text { genes }\end{array}$ & NCCN guidelines \\
\hline & $\begin{array}{l}\text { EndoPredict test } \\
\text { Breast cancer }\end{array}$ & $\begin{array}{l}\text { RT-PCR } \\
12 \text { genes }\end{array}$ & NCCN guidelines \\
\hline
\end{tabular}

TMB, tumor mutational burden; HRD, homologous repair deficiency; CDx, companion diagnostics; NCCN, national comprehensive cancer network.

\subsection{Molecular Target Discoveries and NGS Panel Sequencing}

Imatinib (Gleevec) - targeting BCR-ABL in chronic myeloid leukemia-is one of the most successful molecular-targeted therapies for genetic aberrations in cancer [7]. It took 30 years from the discovery of the truncated chromosome 22-Philadelphia chromosometo the identification of the $B C R-A B L$ gene fusion and another 10 years for the clinical trial on the tyrosine kinase inhibitor imatinib [8]. Next generation sequencing (NGS) enabled the analysis of the entire human genome and influenced the launching of cancer genome projects such as The Cancer Genome Atlas (TCGA) - in 2005-and the International Cancer Genome Consortium (ICGC) in 2008 [9], which led the community efforts to obtain a comprehensive understanding of the genomic alterations underlying all major cancers. Starting from the first markup study on the glioblastoma genome [10], TCGA has provided insights into the genomic landscapes of over 33 cancer types [11] and ICGC has provided insights into the genomic landscapes of over 50 cancer types in less than 15 years. It suffices to say that now we have a genomic draft for major cancer types. The draft, which focused on the protein-coding regions and expanded to the non-coding areas of the human genome, remarkably accelerated the discovery of genetic aberrations in cancer.

While whole genome, exome, or transcriptome sequencing provide more extensive information about genomic alterations in cancer, currently only gene panel sequencing is employed in clinical settings [11,12]. Oncomine Dx Target Test, FoundationOne CDx, and MSK-IMPACT are the representative US FDA-approved NGS panel platforms covering different ranges of point mutations, gene amplifications, translocations, and complex genomic features such as tumor mutational burden (TMB) or homologous recombination deficiency (HRD) that guide molecular-targeted therapies in lung cancer or multiple cancer types [13]. The tangent from the emergence of cancer genomics to the clinical implementation of panel sequencing indicates the requirement of two parallel areas of research, i.e., one linking genomic alterations to treatment response $[14,15]$ and the other involving the formulation of efficient strategies for detecting clinically significant alterations [16].

Association of genomic alterations with treatment response in cancer is categorized in multiple tiers [14], with druggable mutations used in companion diagnostics (CDx) at the highest level, cancer mutations with evidence of clinical significance at the second level, and cancer mutations with potential clinical significance at the third level. For example, FoundationOne CDx in the current form detects genetic aberrations in 324 genes and three genomic features, i.e., microsatellite instability (MSI), TMB, and HRD status [17]. Among these, CDx indications include non-small cell lung cancer (NSCLC) with EGFR exon 19 deletions and EGFR exon 21 L858R alterations (for afatinib, gefitinib, or erlotinib); EGFR exon 20 T790M for osimertinib; $A L K$ rearrangements (for alectinib, crizotinib, or ceritinib); 
and BRAF V600E (for dabrafenib in combination with trametinib). Additional indications include melanoma with $B R A F$ 600E and V600K alterations, breast cancer with ERBB2 (HER2) amplification, colorectal cancer with KRAS wild-type (absence of mutations in codons 12 and 13, or exons two, three, and four) and NRAS wild-type, and ovarian cancer with $B R C A 1 / 2$ alterations. TMB (>10 mutations per megabase) can be used as a marker for the outcomes of pembrolizumab immune checkpoint therapy in solid tumors. CDx level genomic alterations are relatively few among all the detected genetic aberrations in a given assay, but are slowly expanding with the emergence of stronger evidence of clinical significance, as seen in the case of NTRK gene fusion [18].

\subsection{Gene-Expression-Based Patient Stratification}

Another example of the involvement of genomic datasets in the clinical decisionmaking process is prognostic testing. Oncotype Dx and Mammaprint are representative assays used in the recurrence risk assessment of early-stage breast cancer [19]. Oncotype Dx provides a recurrence score obtained from RT-PCR-based expression data of 21 genes, and Mammaprint reveals the risk of distant recurrence 10 years after diagnosis based on a microarray-based gene expression score of 70 genes [20]. These assays are recommended in clinical guidelines, such as the National Comprehensive Cancer Network (NCCN) and the American Society of Clinical Oncology (ASCO), as prognostic and therapy-predictive (Oncotype Dx only) assays complementing other clinical data. In multiple myeloma, MyPRS [21] and SKY-92 [22] provide microarray-based gene expression signature scores for risk stratification. However, these remain investigational, and their clinical implementation requires further validation. Though development of gene-expression-based complementary diagnostics has relied on the accumulation of microarray data with clinical annotations over many years, RNA sequencing has now emerged as the preferred method for high-throughput gene expression analysis. By comparison, RT-PCR is mostly employed as an assay for evaluating the expression of a small number of genes and is comparable to the panel sequencing strategy that is used for the efficient detection of selective DNA aberrations.

\section{Tumor Heterogeneity Is Responsible for Treatment Resistance in Precision Oncology}

Heterogeneous tumor cell populations-with variations in the proliferative capacity, tumor antigen expression, immune cell activation, or other characteristics affecting tumor growth and the response to anti-cancer drugs-are present within a single tumor. Intratumoral heterogeneity, investigated based on protein marker expression in tissues or isolated tumor populations-before the genomics era-has long been suspected to be responsible for the development of treatment resistance. Genomic analyses nowadays allow the systemic assessment of tumor cell properties, and multi-regional or single-cell genomics elaborate on the degree of intratumoral heterogeneity and its effects.

\subsection{Tumor Heterogeneity Fine-Tuning Molecular-Targeted Therapies}

As conditions associated with genomic instability, tumors evolve to generate multiple clones with discrete genomic profiles [23]. Multi-regional and longitudinal genomic studies on cancer have demonstrated the presence of genetic clones with different mutations, copy number alterations, and multiple epigenome and transcriptome profiles in a single patient [24,25]. Intratumoral heterogeneity poses a serious challenge in genome-based molecular-targeted therapy, as pre-existing non-target populations persist and result in disease relapse. To avoid the incomplete targeting of subset populations, treatments directed at truncal mutations shared by all tumor cells or drug combinations targeting all subclones can be adopted [26]. This approach involves the inclusive sampling of tumor tissues representing the whole tumor, which is difficult to achieve with biopsy specimens. Furthermore, tumor evolution has a much broader scope than that of pre-existing non-target clones. In a recent series of publications, the TRAcking non-small cell lung Cancer Evolution through therapy (TRACERx) consortium demonstrated spatial tumor heterogeneity in lung 
cancer arising from genetic evolution, transcriptomic diversification, and interplay with the immune microenvironment [27-33].

While multi-regional or multi-temporal sequencing is mainly used for the phylogenetic reconstruction of tumor evolution, tumor subclonal heterogeneity can be estimated within a single tumor sample based on the variant allele frequency of single nucleotide variants (SNVs) and large copy number alterations (CNAs) [34]. Tumor subclonal heterogeneity, which can be estimated from bulk sequencing data, is associated with more aggressive tumor growth, metastasis, and treatment resistance $[25,35,36]$. DNA sequencing at the single cell or the single nucleus levels also enables the reconstruction of subclonal structures in cancer, with both advantages and disadvantages compared to bulk analysis [37]. Singlecell or nuclear CNA overcomes the issues associated with ambiguities in tumor purity or ploidy as well as insensitivities to rare clones, if successfully captured, in bulk samples. However, the small number of assayed cells may not represent the diverse subclonal populations in the whole tumor. Uneven and low genome coverage due to the limited starting material and the extensive amplification also introduce errors in the estimation of CNA in single cells [37]. While ongoing technical advancement continues to increase the resolution and the scope of single-cell/nucleus-level DNA analysis in the reconstruction of tumor evolutionary paths [38], these limitations yield a bias and an underestimation of subclonal heterogeneity at single-cell resolution. Thus, in the estimation of genetic heterogeneity, bulk-level analyses are likely to provide reliable information regarding the complex subclonal structures that may affect the efficacy of molecular-targeted therapies.

Detection of genetic aberrations in circulating tumor cells (CTCs) or in tumor cells of minimal/measurable residual disease (MRD) could provide an early window for molecular target selection ahead of metastasis or relapse [39]. The frequencies of CTCs in solid tumors or in the residual tumor load during remission are extremely low, and bulk genomic analysis often fails to capture the tumor cell signals. Enrichment of EPCAM+CD45-cells and subsequent single-cell DNA sequencing, rather than simple enumeration, could provide information regarding the genetic characteristics of CTCs with a high metastatic potential in solid tumors. In acute myeloid leukemia (AML), tumor clones can be detected in $80 \%$ of patients during remission using single-cell sequencing [40]. While single-cell level DNA sequencing allows for more comprehensive genetic profiling of specific tumor clones, capturing rare tumor clones requires large numbers of single-cell sampling. Thus, the development of an efficient target cell capture platform - in terms of throughput and costis required for the practical use of single-cell genomics for monitoring the CTCs or residual tumor load.

\subsection{Gene Expression Heterogeneity Associated with Prognosis, Treatment, and Patient Stratification}

Unlike the assessment of genotype diversity at the DNA level, intratumoral heterogeneity assessment based on gene expression data requires analyses at a single-cell resolution due to its quantitative nature. At the tissue level, gene expression data have been used for tumor subtype assessment and patient stratification in multiple cancer types [41-43]. As scRNA-seq data dissect gene expression heterogeneity at the cellular level, the tumor subtype classification gets updated to distinguish tumor signatures and stromal characteristics surrounding the tumor [44] (Figure 2 and Table 2). 
Table 2. Single-cell studies dissecting tumor signatures and specific microenvironment.

\begin{tabular}{|c|c|c|c|}
\hline Tumor Type & Technology & Main Findings & References \\
\hline NSCLC & scRNA-seq & $\begin{array}{l}\text { A cancer cell subtype deviating from the normal differentiation trajectory is } \\
\text { associated with poor survival in lung adenocarcinoma. Metastatic lung cancer } \\
\text { reveals pro-tumoral and immunosuppressive microenvironment along with } \\
\text { expansion of monocyte-derived macrophages and dendritic cells, and } \\
\text { exhausted T-cells. }\end{array}$ & [45] \\
\hline NSCLC & scRNA-seq & $\begin{array}{c}\text { Heterogenous epithelial cell types spread along cancer } \\
\text { developmental trajectories. } \\
\text { Rare cell types such as follicular dendritic cells and T helper } 17 \text { cells are } \\
\text { identified in the advanced NSCLC. } \\
\text { cDC2 displayed Langerin (CD207) is associated with clinical outcomes in } \\
\text { lung adenocarcinoma. }\end{array}$ & [46] \\
\hline Breast cancer & snDNA-seq & $\begin{array}{l}\text { Aneuploid rearrangements burst early in tumor evolution. } \\
\text { Point mutations evolve gradually to produce extensive clonal diversity. }\end{array}$ & [47] \\
\hline Breast cancer & $\begin{array}{l}\text { scDNA-seq; } \\
\text { scRNA-seq }\end{array}$ & Subclones associated with chemoresistance are pre-existing in the tumor. & [48] \\
\hline Colon cancer & scRNA-seq & $\begin{array}{l}\text { The classification according to consensus molecular subtypes reflects both the } \\
\text { tumor and its associated microenvironment. } \\
\text { Heterogeneous copv number alterations explain intra- and inter-patient }\end{array}$ & [49] \\
\hline Ovarian cancer & scRNA-seq & $\begin{array}{c}\text { Heterogeneous copy number alterations explain intra- and inter-patient } \\
\text { variation of malignant cells. } \\
\text { Diverse subsets of cancer-associated fibroblasts and macrophages show } \\
\text { inter-patient variability. }\end{array}$ & [50] \\
\hline Glioblastoma & scRNA-seq & $\begin{array}{l}\text { Four cellular states of malignant cells are identified in glioblastoma, which are } \\
\text { influenced by their associated microenvironment and exhibit plasticity. }\end{array}$ & [51] \\
\hline Glioblastoma & scRNA-seq & $\begin{array}{l}\text { Glioblastoma subtypes which have variable expression in diverse } \\
\text { transcriptional programs and prognostic implications are identified. } \\
\text { Head and neck squamous cell carcinoma (HNSCC) subtype vary in cell cycle, }\end{array}$ & [1] \\
\hline Head and neck cancer & scRNA-seq & $\begin{array}{l}\text { stress, hypoxia, and epithelial differentiation. } \\
\text { A partial epithelial-to-mesenchymal transition (p-EMT), one of HNSCC } \\
\text { subtypes, is a predictor of metastasis and progression. }\end{array}$ & [52] \\
\hline Melanoma & scRNA-seq & $\begin{array}{l}\text { Diverse transcriptional heterogeneity across malignant cells within a tumor is } \\
\text { related to the cell cycle, spatial context, and a drug-resistance program. } \\
\text { Malignant cells with elevated levels of AXL and MITF coexist in melanoma. }\end{array}$ & [2] \\
\hline
\end{tabular}

First, single tumor sites were frequently populated by multiple tumor subtype cells, implying compound tumor cell behavior. In glioblastoma, individual tumor cells in a single patient can be classified into diverse subtypes, such as proneural, neural, classical, and/or mesenchymal types, as well as hybrid cell types [1]. This multiple subtype composition and hybrid status suggested a variation in the susceptibility of tumor cells to conventional and molecular-targeted therapies and underscored their plasticity as well. In addition, in breast cancer, the presence of the rare triple-negative breast cancer (TNBC) subtype cells in estrogen receptor (ER)-positive tumors indicated the existence of pre-existing tumor clones with intrinsic resistance to hormone therapy [53]. Second, tissue-level mesenchymal subtypes associated with poor patient survival reflect the overabundance of cancer-associated fibroblasts (CAFs) in colorectal and ovarian cancers $[49,50,54]$. In these tumors, conventional gene expression patterns signifying an epithelial-mesenchymal transition (EMT) were found to originate from CAFs rather than from tumor cells. In head and neck squamous cell carcinoma, partial EMT programs that are different from the conventional EMT signatures have been identified [52]. Identification of transcriptional programs governing the epithelial tumor cell-specific EMT could help redefine the regulatory pathways of metastasis and may reveal new strategies to control the metastatic phenotype. Third, the gene expression phenotype of tumor cells could be linked to molecular-targeted therapies and drug combinations. The presence of two tumor subpopulations with mutually exclusive EGFR or SRC signaling pathways facilitated the prediction of drug combinations, for which the efficacy was validated using a patient-derived tumor xenograft mouse model [5]. In addition, tumor cell-specific expression of a drug target may reinforce the utilization of genome-based molecular-targeted therapy [55]. Fourth, immune cell profiling demonstrated that $\mathrm{T}$ cell or myeloid cell phenotypes influenced the success of immune checkpoint therapies. In the past decade, remarkable responses to immune checkpoint therapy (ICT) using therapeutic agents such as programmed death-1/programmed death ligand-1 (PD-1/PD-L1) and cytotoxic T lymphocyte antigen-4 (CTLA4) inhibitors have 
been reported to have a huge impact on the management of cancer and development of cancer immunotherapies. Melanoma and lung cancer were the first tumor types against which ICT had shown efficacy; however, the overall response rate in these types was found to be less than $20 \%$. Patient selection based on high PD-L1 expression-identified by immunohistochemistry or high TMB (or tumor neoantigen)—has increased the response rate to $40-60 \%$ [56]. As PD-L1 expression and high TMB resulted in the recapitulation of the immune cell-rich phenotype, immune profiling of the peripheral blood or tumor-infiltrating leukocytes (TILs) also predicted the response to ICT at some levels [57]. Nonetheless, this prediction is insufficient, and improved prediction methods could increase the success rate of ICT and aid the development of new strategies targeted at promoting tumor-directed immunity. In the single-cell genomic approach, immune cell profiling can be achieved at a much higher resolution, covering both cell types and cellular states (Table 3).

Table 3. Single-cell studies identifying immune cells associated with response to immune checkpoint inhibitor.

\begin{tabular}{|c|c|c|c|c|c|}
\hline Tumor Type & Sample Source & Technology & Cell Subset & Association & References \\
\hline Melanoma & TILs & Flow cytometry & $\begin{array}{l}\text { PD-1 hi CTLA-4 hi } \\
\text { CD8+ T cell }\end{array}$ & $\begin{array}{l}\text { Relative abundance of PD-1hiCTLA-4hi } \\
\text { cells within the tumor-infiltrating CD8+ T } \\
\text { cell subset correlates with response to } \\
\text { checkpoint inhibitors and survival. } \\
\text { The invigoration of circulating }\end{array}$ & [58] \\
\hline Melanoma & PBMCs TILs & Flow cytometry & Tex cell & $\begin{array}{l}\text { exhausted-phenotype CD8+ } \mathrm{T} \text { (Tex) cells in } \\
\text { relation to tumor burden correlates with } \\
\text { clinical response to PD-1 blockade. }\end{array}$ & [59] \\
\hline NSCLC & PBMCs & Flow cytometry & PD-1+CD8+ T cell & $\begin{array}{l}\text { PD-1+ CD8+ T cell in peripheral blood } \\
\text { correlates with clinical benefit after } \\
\text { receiving PD-1-targeted therapies. } \\
\text { Anti-PD-1 induces the expansion of }\end{array}$ & [60] \\
\hline Melanoma & TILs & $\begin{array}{l}\text { Mass cytometry; } \\
\text { RNA-seq }\end{array}$ & $\begin{array}{l}\text { Tex cell; } \\
\text { ICOS+ Th1-like CD4 } \\
\text { effector cell }\end{array}$ & $\begin{array}{l}\text { tumor-infiltrating exhausted-like CD8+ T } \\
\text { cells (Tex), but anti-CTLA-4 induces the } \\
\text { expansion of the ICOS+ Th1-like CD4 } \\
\text { effector cells in addition to Tex cells. }\end{array}$ & [61] \\
\hline NSCLC & TILs & $\begin{array}{l}\text { Flow cytometry; } \\
\text { RNA-seq }\end{array}$ & PD-1+ CD8+ T cell & $\begin{array}{l}\text { The presence of CD }+ \text { T lymphocyte with } \\
\text { high PD-1 expression is strongly predictive } \\
\text { for response to PD-1 blockade and } \\
\text { better survival. }\end{array}$ & [62] \\
\hline Melanoma & tumor & $\begin{array}{l}\text { scRNA-seq; } \\
\text { ATAC-seq }\end{array}$ & TCF7+ CD8+ T cell & $\begin{array}{l}\text { The presence of TCF7+ CD8+ T cells } \\
\text { predicts response to checkpoint inhibitors } \\
\text { and positive clinical outcome. }\end{array}$ & [63] \\
\hline Melanoma & tumor & $\begin{array}{c}\text { RNA-seq; } \\
\text { Multiplex IHC; CyTOF }\end{array}$ & $\begin{array}{l}\text { EOMES+ CD69+ } \\
\text { CD45RO+ effector } \\
\text { memory T cell }\end{array}$ & $\begin{array}{c}\text { EOMES+CD69+CD45RO+ effector } \\
\text { memory T cell phenotype is associated } \\
\text { with response to checkpoint inhibitors and } \\
\text { longer survival. }\end{array}$ & [64] \\
\hline Melanoma & $\begin{array}{l}\text { TILs } \\
\text { PBMCs }\end{array}$ & $\begin{array}{l}\text { Flow cytometry; } \\
\text { RNA-seq }\end{array}$ & Tex cell & $\begin{array}{l}\text { The accumulation of exhausted CD8 T } \\
\text { (Tex) cells in the tumor was associated with } \\
\text { clinical benefit and response to anti-PD- } 1 \text {. }\end{array}$ & [65] \\
\hline $\begin{array}{l}\text { Melanoma; } \\
\text { Head\&Neck; } \\
\quad \text { Breast; } \\
\text { Urothelial; Renal; } \\
\text { Lung; Colorectal }\end{array}$ & $\begin{array}{l}\text { tumor } \\
\text { TILs }\end{array}$ & $\begin{array}{l}\text { RNA-seq; } \\
\text { scRNA-seq }\end{array}$ & $\begin{array}{c}\text { CXCL9/CXCL13 CD8+ } \\
\text { T cell }\end{array}$ & $\begin{array}{c}\text { Clonal TMB and CXCL9/CXCL10 } \\
\text { expression in tumor-infiltrating CD8+ T } \\
\text { cells predicts response to } \\
\text { checkpoint blockade. }\end{array}$ & [66] \\
\hline $\begin{array}{l}\text { Renal cell } \\
\text { carcinoma }\end{array}$ & $\begin{array}{l}\text { tumor } \\
\text { lymph node } \\
\text { PBMCs }\end{array}$ & scRNA-seq & $\begin{array}{c}\text { CD8A+ tissue-resident } \\
\text { T cell }\end{array}$ & $\begin{array}{l}\text { The abundance of CD8A+tissue-resident } \mathrm{T} \\
\text { cells is associated with response to } \\
\text { immune checkpoint blockade and } \\
\text { improved survival. }\end{array}$ & [67] \\
\hline Gastric cancer & tumor & scRNA-seq & PD-1+CD8+ T cell & $\begin{array}{c}\text { The abundance of PD- } 1+\text { CD } 8+T \text { cells } \\
\text { correlate with response and longer } \\
\text { survival to PD-1 blockade. }\end{array}$ & [68] \\
\hline
\end{tabular}

Comparison between responders and non-responders provides critical information regarding patient stratification and the mechanism of action of ICT [69]. Characterization of post-treatment samples helps define the immune cell dynamics and state transitions [70]. Overall, effector-memory CD8+ T cells are known to be associated with a positive response to ICT $[61,64]$. Exhausted phenotype T cells, likely including both activated and exhausted populations, have been reported to predict a positive ICT response in melanoma, NSCLC, and basal cell carcinoma [58-62,65,71,72]. In a more recent study, Transcription Factor 7 (TCF7) - but not PDCD1 (PD-1 gene) —expression, was found to be a positive predictor of tumor regression in melanoma [63]. In MSI-high gastric cancer, a diverse T cell receptor (TCR) repertoire and the presence of early-to-intermediate activation status $\mathrm{T}$ cells in tumor tissues were found to be associated with an ICT response [68]. As T cell activation and exhaustion are confounding processes, exhaustion markers are good indicators of 
the presence of tumor-directed immunity; however, terminal differentiation of collective tumor-specific $\mathrm{T}$ cells in the exhausted state may adversely influence the ICT response. Single-cell genomics is a robust tool for defining the dynamic balance between $\mathrm{T}$ cell activation and exhaustion.

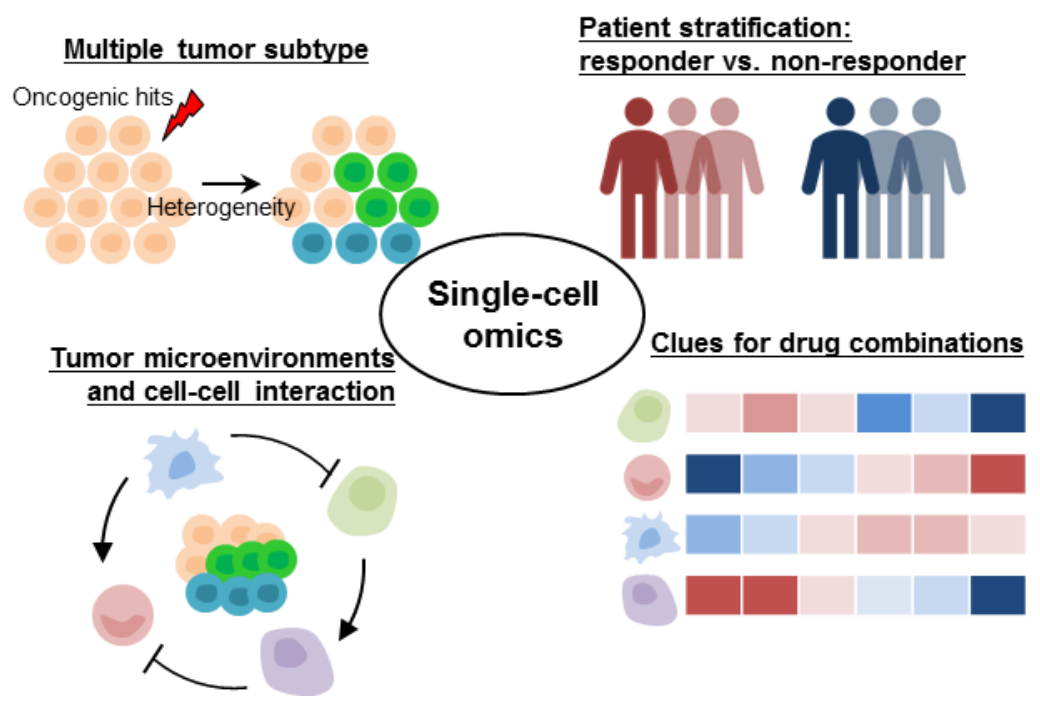

Figure 2. Gene expression heterogeneity in cancer addressed by scRNA-seq.

4. Multimodal and Deconvolution Approaches Facilitate the Biological Interpretations and Clinical Applications of Single-Cell Genomic Data

Among many single-cell genomic tools, transcriptome analysis is most frequently used to evaluate intratumoral heterogeneity due to the scalability of technology and the feasibility of phenotypic translation. Several attributes need to be considered to exploit the biological and clinical interpretations of single-cell transcriptome data (Figure 3).

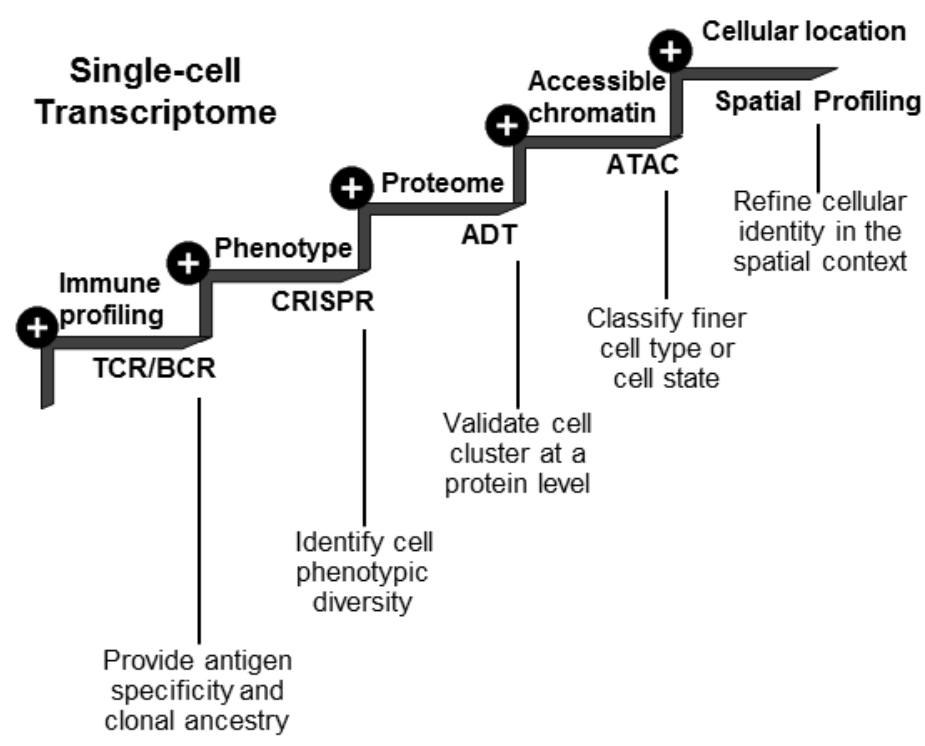

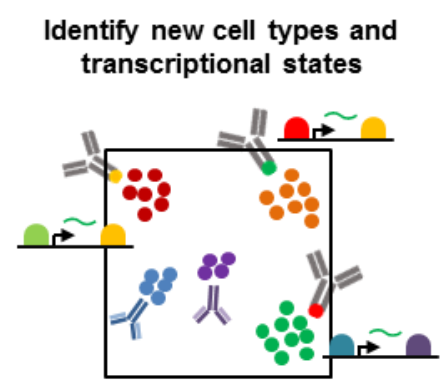

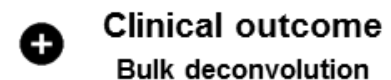

Bulk deconvolution

Overcome the limitations in the cost and sampling

Figure 3. Integrative approaches using single-cell multi-modal omics.

Both genetic and non-genetic mechanisms are likely to influence heterogeneity at the level of gene expression. Heterogeneity arising from tumor-intrinsic genetic evolution or non-genetic alterations triggered by microenvironmental factors is associated with distinct indications that enable the heterogeneity-associated treatment resistance to be overcome, depending on the source. Thus, linking genetic data with gene expression heterogeneity is 
important to determine how to use the information for therapeutic advancement. Another important aspect of single-cell transcriptome analysis is the uncertainty in the number of clusters or subpopulations. Defining biologically meaningful clusters requires prior knowledge of gene expression obtained using well-isolated population data with functional corroboration. As the isolation procedures rely on a few surface protein markers, it is often the protein expression profile that defines a functional subpopulation. Therefore, the inference of transcriptome-based clusters needs to be validated by the simultaneous measurement of corresponding surface markers and gene expression. Finally, the use of single-cell RNA sequencing has practical limitations in terms of the cost and the associated sampling breadth. Though the cost has dropped substantially-and will continue to decrease-and the sampling breadth has increased, the output cell numbers in most studies remain below 3000 cells per sample, which may not be enough to cover extensive heterogeneity in complex tissues. Deconvolution methods using bulk genomic data-both at the genetic and the gene expression levels-may overcome the limitations associated with cost and sampling and could also provide an opportunity to treat a large number of patients besides offering substantial clinical annotations.

\subsection{Linking Genetic and Gene Expression Data}

Combining single-cell DNA and gene expression data may reveal tumor heterogeneity that could result in the translation of genetic evolution into transcriptional phenotypes. Multi-omics data generation methods [73] such as G\&Tseq [74] and Trioseq [75]. Alternatively, genetic features, such as mutations and CNA, can be measured or inferred from scRNA-seq data (Table 4).

Table 4. Genetic features assessed by scRNA-seq.

\begin{tabular}{|c|c|c|c|}
\hline Genetic Feature & Method & Tool Name & References \\
\hline CNA & $\begin{array}{l}\text { chromosomal gene } \\
\text { expression pattern }\end{array}$ & $\begin{array}{c}\text { inferCNV } \\
\text { CopyKAT } \\
\text { CaSpER } \\
\text { HoneyBADGER } \\
\text { scCNAutils } \\
\text { CONICS }\end{array}$ & $\begin{array}{c}\text { https: / / github.com/ } \\
\text { broadinstitute/inferCNV, } \\
\text { accessed on 15 July 2021 } \\
{[76]} \\
{[77]} \\
{[78]} \\
{[79]} \\
{[80]}\end{array}$ \\
\hline \multirow{2}{*}{ Mutation } & $\begin{array}{l}\text { targeted genotyping of } \\
\text { CDNA }\end{array}$ & GoT & [81] \\
\hline & statistical method & $\begin{array}{c}\text { SCMut } \\
\text { DENDRO }\end{array}$ & $\begin{array}{l}{[82]} \\
{[83]}\end{array}$ \\
\hline
\end{tabular}

Detection of SNVs in single-cell RNA sequencing data is hampered by false negatives and positives caused by massive dropouts and amplification errors, respectively. Statistical methods may improve the detection accuracy to some extent $[82,83]$. Nonetheless, many single-cell RNA sequencing data do not cover full-length transcripts, and sequence variation analysis at specific sites remains an inefficient method to determine the clonality of tumor cells, even with full-length data. Inference of DNA CNAs from quantitative chromosomal gene expression data could provide a more robust method to identify genetic clones with large CNAs [76-80]. The supplementary use of single nucleotide polymorphisms (SNPs) increases the resolution of copy number inference and reconstruction of the clonal architecture [77,78].

CNA inference from single-cell gene expression data revealed that clonal evolution accompanies transcriptional heterogeneity in multiple cancer types, including myeloma, breast cancer, and glioblastoma $[76,78,80]$. In these studies, the genetic evolution potentially leading to the phenotype transition of tumor cells toward metastasis and treatment resistance could be identified. Transcriptional heterogeneity that is not recapitulated at the CNA level may indicate incomplete inference, other genomic events, and/or influences from microenvironmental factors. 


\subsection{Linking Protein and Gene Expression Clusters to the Functional Phenotype through Multi-Omic Analyses}

The inference obtained from transcriptional clusters and a sparse gene expression necessitates cluster validation at the protein level, which might be provided by independent analyses such as flow cytometry or mass cytometry. Ideally, the use of antibody-derived tag (ADT) labeling cell surface proteins together with scRNA-seq $[84,85]$ would result in the demarcation of transcriptional clusters linked to protein marker-defined subpopulations. As the ADT method is dependent on the specific binding of antibodies, combined usage with gene expression results in the generation of more reliable reference cell types [86]. An additional data type, i.e., chromatin accessibility, allows for a more refined cell type or cell state classification [87]. The direct projection of transcriptional clusters onto the functional phenotype can be achieved by single-cell clustered regularly interspaced short palindromic repeat (CRISPR) screening [87-89]. Moreover, spatial profiling using single-cell or spatial transcriptomics $[90,91]$ uncovers the location of specific cell populations and their neighbors, further refining cellular identities and substantiating cellular interactions. Overall, multimodal data bridge biomarkers (from any data type) and functional phenotypes, help refine the cell type and cell state annotations, and allow for a mechanistic dissection for phenotype control.

\subsection{Linking Single-Cell Gene Expression Data to Clinical Output through Bulk Deconvolution}

Despite the high-resolution cell type or transcriptional state information, the availability of single-cell gene expression data with clinical annotations is limited when compared to the bulk tissue-level data. Therefore, once cellular characteristics are defined at a single-cell resolution, tissue-level gene expression data are used to validate the clinical significance of the findings from the single-cell data. (Table 5 and Figure 4).

Table 5. Tumor studies using scRNA-seq data for bulk RNA-seq deconvolution.

\begin{tabular}{|c|c|c|c|}
\hline Tumor Type & Deconvolution Approaches & Main Findings & References \\
\hline \multicolumn{4}{|c|}{ Signature gene sets } \\
\hline Triple negative breast cancer & $\begin{array}{l}\text { Inference of tissue-resident memory T (Trm) } \\
\text { gene signature expression level }\end{array}$ & $\begin{array}{c}\text { Association with improved patient survival rate in } \\
\text { early-stage TNBC }\end{array}$ & [92] \\
\hline Melanoma & $\begin{array}{l}\text { Inference of T cell infiltration levels and } \\
\text { malignant genes correlated with T } \\
\text { cell infiltration }\end{array}$ & Genes associated with T cell exclusion program & [70] \\
\hline Nasopharyngeal carcinoma & $\begin{array}{l}\text { Correlations of } 17 \text { immune subtype signatures } \\
\text { with clinicopathological features }\end{array}$ & $\begin{array}{c}\text { Immune subsets significantly associated with better } \\
\text { survival outcomes }\end{array}$ & [93] \\
\hline Gastric cancer & Inference of M2-like TAM level & $\begin{array}{l}\text { Improved prediction of poor survival by high } \\
\text { M2 signature }\end{array}$ & [94] \\
\hline \multicolumn{4}{|c|}{ Cellular deconvolution } \\
\hline Melanoma & $\begin{array}{l}\text { (CIBERSORTx) Deconvolution into major } \\
\text { cell types }\end{array}$ & $\begin{array}{l}\text { (1) Cellular signatures within malignant cells and CAFs } \\
\text { according to BRAF or NRAS mutation status } \\
\text { (2) CD8 T cell signatures associated with anti-PD1 or } \\
\text { anti-CTLA4 therapy response }\end{array}$ & [95] \\
\hline $\begin{array}{l}\text { Adrenal } \\
\text { Neuroblastoma }\end{array}$ & $\begin{array}{l}\text { (MuSiC) Deconvolution into developing } \\
\text { cell populations }\end{array}$ & $\begin{array}{l}\text { (1) Three tumor groups; Undifferentiated chromaffin cell } \\
\text { (UCHC)-like, Differentiated chromaffin cell (DCHC)-like, } \\
\text { and EMT NCC-like } \\
\text { (2) EMT NCC-like tumors had the worst survival rate, } \\
\text { while DCHC-like tumors had the better survival rate }\end{array}$ & [96] \\
\hline Bladder cancer & $\begin{array}{l}\text { (CIBERSORTx) Deconvolution into fine subsets } \\
\text { of cell types }\end{array}$ & $\begin{array}{c}\text { Accumulation of a CAF subtype associated with poor } \\
\text { overall survival }\end{array}$ & [97] \\
\hline $\begin{array}{l}\text { Head and Neck Squamous Cell } \\
\text { Carcinoma }\end{array}$ & $\begin{array}{l}\text { (CIBERSORTx \& MuSiC) Deconvolution into T } \\
\text { cell subpopulations }\end{array}$ & $\begin{array}{l}\text { High proportions of regulatory T cells as the major } \\
\text { contributor of improved survival rate }\end{array}$ & [98] \\
\hline Renal cell carcinoma & $\begin{array}{l}\text { (CIBERSORTx) Infererence of CXCL10-Hi TAM } \\
\text { and CD8+ T cell fraction wthin on-ICB T cells }\end{array}$ & $\begin{array}{l}\text { Positive correlation between CXCL10-Hi TAM fraction } \\
\text { and the amount of interferon gamma expressed by CD8 }\end{array}$ & [99] \\
\hline
\end{tabular}

First, deconvolution approaches would facilitate the inference of the cell type composition from the bulk gene expression data. Performance testing of different deconvolution methods using pseudo-bulk single-cell RNA sequencing data demonstrated that linear data transformation, an all-inclusive reference matrix, and sensible marker selection are required to achieve high concordance between the proportions of expected and calculated cell types [100]. The resolution of deconvolution approaches is confined to well-defined global cell types, whereas single-cell data allow for a fine subpopulation analysis with distinct and even transitional transcription states. The second approach involves correlation 
or enrichment analysis of gene expression signatures derived from a subpopulation in the single-cell data. In this approach, correlation or enrichment scores are used to portray bulk gene expression data, with more flexibility than the deconvolution approaches. Cancer cell programs [70] and immune cell programs [101,102] derived from single-cell data have been utilized to evaluate bulk datasets and are linked to clinical disease courses. As more scRNA-seq data are generated with clinical annotations, direct comparisons of fine cellular dynamics and disease courses will become available.

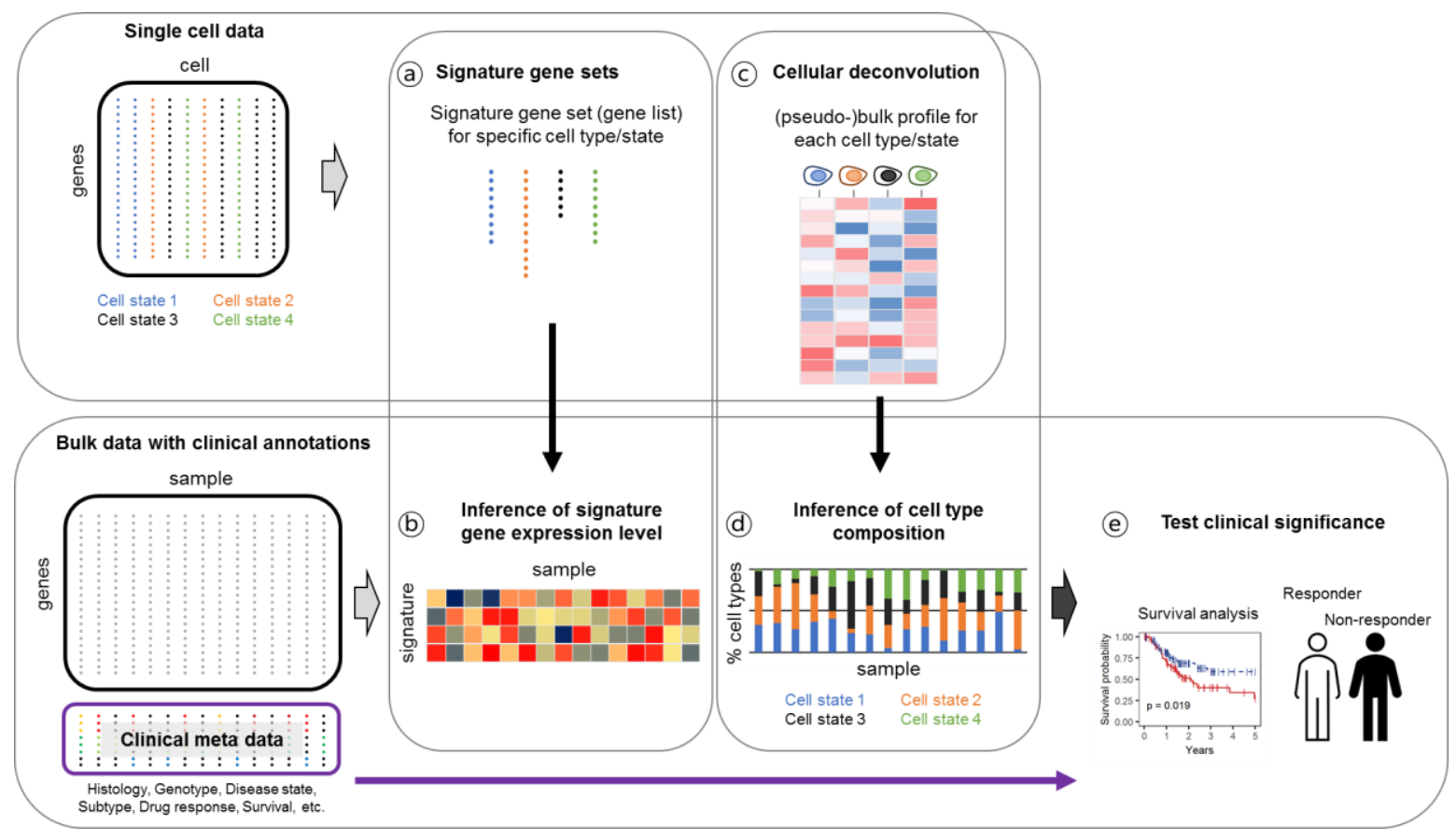

Figure 4. Strategies linking single cell gene expression analysis and bulk-level clinical data.

\subsection{Using BCR and TCR Data for Lineage Tracing and Therapeutic Development}

Single-cell RNA sequencing analysis has revealed the whole combinatorial sequences of BCR and TCR allow for the lineage tracing of clonal B/plasma cells and T cells, respectively. Lineage tracing involves direct comparison of a patient's $\mathrm{T}$ cells collected from different regions, such as the blood and the normal and tumor tissues, as well as the T cells at various differentiation stages. Through simultaneous gene expression and TCR analyses, high levels of clonal expansion have been identified in cytotoxic $\mathrm{T}$ cells from normal tissues and exhausted/cytotoxic T cells from tumor tissues $[103,104]$. Clonal expansion of tumorinfiltrating $\mathrm{T}$ cells suggests a potential tumor reactivity that might be further propagated by immune checkpoint inhibitors. In addition to tracking $\mathrm{T}$ cell or antibody responses, TCR or BCR sequences may also be used for the development of novel treatments in the future. Therapeutic antibody development using this reversal approach has been adopted in noncancer conditions such as COVID-19 infection or vaccination [105,106], where antigenic specificity can be easily tested. Finding tumor antigen specificities is a challenging task and currently limits the direct use of BCR or TCR sequences.

\section{Conclusions}

Single-cell genomics enables the fine-tuning of cancer genomics to a cellular resolution and broadens the scope of cancer cell biology to the genomic scale. For cellular and molecular dissection, various experimental and analytical methods have been developed to specify the cell types and states that matter, and to enable the molecular features that characterize heterogeneous tumor cells to be distinguished from those characterizing the support cells in the tumor microenvironment. Diverse cell populations comprising tumor 
tissues are not randomly recruited, as they are likely to communicate with each other and form a network that determines the cellular and the molecular landscapes of tumor tissues as an entity $[107,108]$. The molecular characteristics of each cellular component and its interconnections - either promoting or inhibiting tumor growth-are all points that can be leveraged during therapeutic development. Therefore, single-cell genomics and the related multi-omics technologies are exploratory tools that far exceed the scope and effectiveness of preceding bulk genomic analyses.

Beyond being an exploratory tool, single-cell genomics has limited capacity as a field technology for detecting tumor heterogeneity in precision oncology. This limitation is attributed to the current sampling breadth, which may result in a partial representation of the whole tumor. For rare CTCs and residual tumors, single-cell genomics facilitated genomic characterization by enabling partial DNA or RNA analyses. Nonetheless, capturing CTCs and residual tumors requires a very large number of cells-up to billions-for analysis or a high-fold enrichment of target populations. However, single-cell genomics technology represents a very active field of research that links single-cell data directly to the clinical decision-making process.

Author Contributions: Conceptualization, H.-O.L.; writing-original draft preparation, N.K., H.H.E., H.-O.L.; writing-review and editing, N.K., H.H.E., H.-O.L.; visualization, N.K., H.H.E.; supervision, H.-O.L.; project administration, H.-O.L.; funding acquisition, H.-O.L. All authors have read and agreed to the published version of the manuscript.

Funding: This research was supported by National Research Foundation (NRF) funded by the Ministry of Science \& ICT (MSIT), grant number NRF-2017M3C9A6044636 and 2019M3A9B6064691. N.K. and H.H.E. are supported by Basic Science Research Program through NRF funded by the Ministry of Education (NRF-2020R1I1A1A01065697 and NRF-2021R1I1A1A01043906).

Acknowledgments: Discussion and technical comments from Areum Jo and Dasom Jeong (The Catholic University of Korea).

Conflicts of Interest: The authors declare no conflict of interest. The funders had no role in the design of the study; in the collection, analyses, or interpretation of data; in the writing of the manuscript, or in the decision to publish the results.

\section{References}

1. Patel, A.P.; Tirosh, I.; Trombetta, J.J.; Shalek, A.K.; Gillespie, S.M.; Wakimoto, H.; Cahill, D.P.; Nahed, B.V.; Curry, W.T.; Martuza, R.L.; et al. Single-cell RNA-seq highlights intratumoral heterogeneity in primary glioblastoma. Science 2014, 344, 1396-1401. [CrossRef] [PubMed]

2. Tirosh, I.; Izar, B.; Prakadan, S.M.; Wadsworth, M.H., 2nd; Treacy, D.; Trombetta, J.J.; Rotem, A.; Rodman, C.; Lian, C.; Murphy, G.; et al. Dissecting the multicellular ecosystem of metastatic melanoma by single-cell RNA-seq. Science 2016, 352, 189-196. [CrossRef]

3. Aissa, A.F.; Islam, A.; Ariss, M.M.; Go, C.C.; Rader, A.E.; Conrardy, R.D.; Gajda, A.M.; Rubio-Perez, C.; Valyi-Nagy, K.; Pasquinelli, M.; et al. Single-cell transcriptional changes associated with drug tolerance and response to combination therapies in cancer. Nat. Commun. 2021, 12, 1628. [CrossRef]

4. Kim, K.T.; Lee, H.W.; Lee, H.O.; Kim, S.C.; Seo, Y.J.; Chung, W.; Eum, H.H.; Nam, D.H.; Kim, J.; Joo, K.M.; et al. Single-cell mRNA sequencing identifies subclonal heterogeneity in anti-cancer drug responses of lung adenocarcinoma cells. Genome Biol. 2015, 16, 127. [CrossRef] [PubMed]

5. Kim, K.T.; Lee, H.W.; Lee, H.O.; Song, H.J.; Jeong, D.E.; Shin, S.; Kim, H.; Shin, Y.; Nam, D.H.; Jeong, B.C.; et al. Application of single-cell RNA sequencing in optimizing a combinatorial therapeutic strategy in metastatic renal cell carcinoma. Genome Biol. 2016, 17, 80. [CrossRef] [PubMed]

6. Butler, A.; Hoffman, P.; Smibert, P.; Papalexi, E.; Satija, R. Integrating single-cell transcriptomic data across different conditions, technologies, and species. Nat. Biotechnol. 2018, 36, 411-420. [CrossRef] [PubMed]

7. Braun, T.P.; Eide, C.A.; Druker, B.J. Response and Resistance to BCR-ABL1-Targeted Therapies. Cancer Cell 2020, 37, 530-542. [CrossRef] [PubMed]

8. Druker, B.J.; Talpaz, M.; Resta, D.J.; Peng, B.; Buchdunger, E.; Ford, J.M.; Lydon, N.B.; Kantarjian, H.; Capdeville, R.; Ohno-Jones, S.; et al. Efficacy and safety of a specific inhibitor of the BCR-ABL tyrosine kinase in chronic myeloid leukemia. N. Engl. J. Med. 2001, 344, 1031-1037. [CrossRef]

9. International Cancer Genome Consortium; Hudson, T.J.; Anderson, W.; Artez, A.; Barker, A.D.; Bell, C.; Bernabe, R.R.; Bhan, M.K.; Calvo, F.; Eerola, I.; et al. International network of cancer genome projects. Nature 2010, 464, 993-998. [CrossRef] 
10. Cancer Genome Atlas (TCGA) Research Network. Comprehensive genomic characterization defines human glioblastoma genes and core pathways. Nature 2008, 455, 1061-1068. [CrossRef] [PubMed]

11. Gao, G.F.; Parker, J.S.; Reynolds, S.M.; Silva, T.C.; Wang, L.B.; Zhou, W.; Akbani, R.; Bailey, M.; Balu, S.; Berman, B.P.; et al. Before and After: Comparison of Legacy and Harmonized TCGA Genomic Data Commons' Data. Cell Syst. 2019, 9, $24-34 . e 10$. [CrossRef] [PubMed]

12. Mosele, F.; Remon, J.; Mateo, J.; Westphalen, C.B.; Barlesi, F.; Lolkema, M.P.; Normanno, N.; Scarpa, A.; Robson, M.; MericBernstam, F.; et al. Recommendations for the use of next-generation sequencing (NGS) for patients with metastatic cancers: A report from the ESMO Precision Medicine Working Group. Ann. Oncol. 2020, 31, 1491-1505. [CrossRef] [PubMed]

13. Zhong, Y.; Xu, F.; Wu, J.; Schubert, J.; Li, M.M. Application of Next Generation Sequencing in Laboratory Medicine. Ann. Lab. Med. 2021, 41, 25-43. [CrossRef] [PubMed]

14. Perakis, S.O.; Weber, S.; Zhou, Q.; Graf, R.; Hojas, S.; Riedl, J.M.; Gerger, A.; Dandachi, N.; Balic, M.; Hoefler, G.; et al. Comparison of three commercial decision support platforms for matching of next-generation sequencing results with therapies in patients with cancer. ESMO Open 2020, 5, e000872. [CrossRef] [PubMed]

15. Tate, J.G.; Bamford, S.; Jubb, H.C.; Sondka, Z.; Beare, D.M.; Bindal, N.; Boutselakis, H.; Cole, C.G.; Creatore, C.; Dawson, E.; et al. COSMIC: The Catalogue Of Somatic Mutations In Cancer. Nucleic Acids Res. 2019, 47, D941-D947. [CrossRef]

16. De Jesus, S.; Almeida, L.; Peng-Chen, Z.; Okun, M.S.; Hess, C.W. Novel targets and stimulation paradigms for deep brain stimulation. Expert Rev. Neurother. 2015, 15, 1067-1080. [CrossRef]

17. Goldberg, K.B.; Blumenthal, G.M.; Pazdur, R. The First Year of the Food and Drug Administration Oncology Center of Excellence: Landmark Approvals in a Dynamic Regulatory Environment. Cancer J. 2018, 24, 131-135. [CrossRef] [PubMed]

18. Cocco, E.; Scaltriti, M.; Drilon, A. NTRK fusion-positive cancers and TRK inhibitor therapy. Nat. Rev. Clin. Oncol. 2018, 15, 731-747. [CrossRef]

19. Bartlett, J.M.; Bayani, J.; Marshall, A.; Dunn, J.A.; Campbell, A.; Cunningham, C.; Sobol, M.S.; Hall, P.S.; Poole, C.J.; Cameron, D.A.; et al. Comparing Breast Cancer Multiparameter Tests in the OPTIMA Prelim Trial: No Test Is More Equal Than the Others. J. Natl. Cancer Inst. 2016, 108. [CrossRef]

20. Ross, J.S.; Hatzis, C.; Symmans, W.F.; Pusztai, L.; Hortobagyi, G.N. Commercialized multigene predictors of clinical outcome for breast cancer. Oncologist 2008, 13, 477-493. [CrossRef] [PubMed]

21. Shaughnessy, J.D., Jr.; Zhan, F.; Burington, B.E.; Huang, Y.; Colla, S.; Hanamura, I.; Stewart, J.P.; Kordsmeier, B.; Randolph, C.; Williams, D.R.; et al. A validated gene expression model of high-risk multiple myeloma is defined by deregulated expression of genes mapping to chromosome 1. Blood 2007, 109, 2276-2284. [CrossRef] [PubMed]

22. Kuiper, R.; Broyl, A.; de Knegt, Y.; van Vliet, M.H.; van Beers, E.H.; van der Holt, B.; el Jarari, L.; Mulligan, G.; Gregory, W.; Morgan, G.; et al. A gene expression signature for high-risk multiple myeloma. Leukemia 2012, 26, 2406-2413. [CrossRef]

23. Dagogo-Jack, I.; Shaw, A.T. Tumour heterogeneity and resistance to cancer therapies. Nat. Rev. Clin. Oncol. 2018, 15, 81-94. [CrossRef] [PubMed]

24. Gerlinger, M.; Rowan, A.J.; Horswell, S.; Math, M.; Larkin, J.; Endesfelder, D.; Gronroos, E.; Martinez, P.; Matthews, N.; Stewart, A.; et al. Intratumor heterogeneity and branched evolution revealed by multiregion sequencing. N. Engl. J. Med. 2012, 366, 883-892. [CrossRef] [PubMed]

25. Jamal-Hanjani, M.; Wilson, G.A.; McGranahan, N.; Birkbak, N.J.; Watkins, T.B.K.; Veeriah, S.; Shafi, S.; Johnson, D.H.; Mitter, R.; Rosenthal, R.; et al. Tracking the Evolution of Non-Small-Cell Lung Cancer. N. Engl. J. Med. 2017, 376, 2109-2121. [CrossRef] [PubMed]

26. Lee, J.K.; Wang, J.; Sa, J.K.; Ladewig, E.; Lee, H.O.; Lee, I.H.; Kang, H.J.; Rosenbloom, D.S.; Camara, P.G.; Liu, Z.; et al. Spatiotemporal genomic architecture informs precision oncology in glioblastoma. Nat. Genet. 2017, 49, 594-599. [CrossRef] [PubMed]

27. AbdulJabbar, K.; Raza, S.E.A.; Rosenthal, R.; Jamal-Hanjani, M.; Veeriah, S.; Akarca, A.; Lund, T.; Moore, D.A.; Salgado, R.; Al Bakir, M.; et al. Geospatial immune variability illuminates differential evolution of lung adenocarcinoma. Nat. Med. 2020, 26, 1054-1062. [CrossRef] [PubMed]

28. Biswas, D.; Birkbak, N.J.; Rosenthal, R.; Hiley, C.T.; Lim, E.L.; Papp, K.; Boeing, S.; Krzystanek, M.; Djureinovic, D.; La Fleur, L.; et al. A clonal expression biomarker associates with lung cancer mortality. Nat. Med. 2019, 25, 1540-1548. [CrossRef]

29. Chemi, F.; Rothwell, D.G.; McGranahan, N.; Gulati, S.; Abbosh, C.; Pearce, S.P.; Zhou, C.; Wilson, G.A.; Jamal-Hanjani, M.; Birkbak, N.; et al. Pulmonary venous circulating tumor cell dissemination before tumor resection and disease relapse. Nat. Med. 2019, 25, 1534-1539. [CrossRef]

30. Ghorani, E.; Reading, J.L.; Henry, J.Y.; de Massy, M.R.; Rosenthal, R.; Turati, V.; Joshi, K.; Furness, A.J.S.; Aissa, A.B.; Saini, S.K.; et al. The $\mathrm{T}$ cell differentiation landscape is shaped by tumour mutations in lung cancer. Nat. Cancer 2020, 1, 546-561. [CrossRef]

31. Joshi, K.; de Massy, M.R.; Ismail, M.; Reading, J.L.; Uddin, I.; Woolston, A.; Hatipoglu, E.; Oakes, T.; Rosenthal, R.; Peacock, T.; et al. Spatial heterogeneity of the T cell receptor repertoire reflects the mutational landscape in lung cancer. Nat. Med. 2019, 25, 1549-1559. [CrossRef]

32. Lopez, S.; Lim, E.L.; Horswell, S.; Haase, K.; Huebner, A.; Dietzen, M.; Mourikis, T.P.; Watkins, T.B.K.; Rowan, A.; Dewhurst, S.M.; et al. Interplay between whole-genome doubling and the accumulation of deleterious alterations in cancer evolution. Nat. Genet. 2020, 52, 283-293. [CrossRef] [PubMed] 
33. Rosenthal, R.; Cadieux, E.L.; Salgado, R.; Bakir, M.A.; Moore, D.A.; Hiley, C.T.; Lund, T.; Tanic, M.; Reading, J.L.; Joshi, K.; et al. Neoantigen-directed immune escape in lung cancer evolution. Nature 2019, 567, 479-485. [CrossRef] [PubMed]

34. Tarabichi, M.; Salcedo, A.; Deshwar, A.G.; Ni Leathlobhair, M.; Wintersinger, J.; Wedge, D.C.; Van Loo, P.; Morris, Q.D.; Boutros, P.C. A practical guide to cancer subclonal reconstruction from DNA sequencing. Nat. Methods 2021, 18, 144-155. [CrossRef]

35. Andor, N.; Graham, T.A.; Jansen, M.; Xia, L.C.; Aktipis, C.A.; Petritsch, C.; Ji, H.P.; Maley, C.C. Pan-cancer analysis of the extent and consequences of intratumor heterogeneity. Nat. Med. 2016, 22, 105-113. [CrossRef]

36. Espiritu, S.M.G.; Liu, L.Y.; Rubanova, Y.; Bhandari, V.; Holgersen, E.M.; Szyca, L.M.; Fox, N.S.; Chua, M.L.K.; Yamaguchi, T.N.; Heisler, L.E.; et al. The Evolutionary Landscape of Localized Prostate Cancers Drives Clinical Aggression. Cell 2018, 173, 1003-1013.e1015. [CrossRef]

37. Mallory, X.F.; Edrisi, M.; Navin, N.; Nakhleh, L. Methods for copy number aberration detection from single-cell DNA-sequencing data. Genome Biol. 2020, 21, 208. [CrossRef] [PubMed]

38. Minussi, D.C.; Nicholson, M.D.; Ye, H.; Davis, A.; Wang, K.; Baker, T.; Tarabichi, M.; Sei, E.; Du, H.; Rabbani, M.; et al. Breast tumours maintain a reservoir of subclonal diversity during expansion. Nature 2021, 592, 302-308. [CrossRef] [PubMed]

39. Pantel, K.; Alix-Panabieres, C. Liquid biopsy and minimal residual disease-Latest advances and implications for cure. Nat. Rev. Clin. Oncol. 2019, 16, 409-424. [CrossRef] [PubMed]

40. Ediriwickrema, A.; Aleshin, A.; Reiter, J.G.; Corces, M.R.; Kohnke, T.; Stafford, M.; Liedtke, M.; Medeiros, B.C.; Majeti, R. Single-cell mutational profiling enhances the clinical evaluation of AML MRD. Blood Adv. 2020, 4, 943-952. [CrossRef] [PubMed]

41. Guinney, J.; Dienstmann, R.; Wang, X.; de Reynies, A.; Schlicker, A.; Soneson, C.; Marisa, L.; Roepman, P.; Nyamundanda, G.; Angelino, P.; et al. The consensus molecular subtypes of colorectal cancer. Nat. Med. 2015, 21, 1350-1356. [CrossRef] [PubMed]

42. Verhaak, R.G.; Hoadley, K.A.; Purdom, E.; Wang, V.; Qi, Y.; Wilkerson, M.D.; Miller, C.R.; Ding, L.; Golub, T.; Mesirov, J.P.; et al. Integrated genomic analysis identifies clinically relevant subtypes of glioblastoma characterized by abnormalities in PDGFRA, IDH1, EGFR, and NF1. Cancer Cell 2010, 17, 98-110. [CrossRef]

43. Weigelt, B.; Mackay, A.; A'Hern, R.; Natrajan, R.; Tan, D.S.; Dowsett, M.; Ashworth, A.; Reis-Filho, J.S. Breast cancer molecular profiling with single sample predictors: A retrospective analysis. Lancet Oncol. 2010, 11, 339-349. [CrossRef]

44. Gonzalez Castro, L.N.; Tirosh, I.; Suva, M.L. Decoding Cancer Biology One Cell at a Time. Cancer Discov. 2021, 11, 960-970. [CrossRef]

45. Kim, N.; Kim, H.K.; Lee, K.; Hong, Y.; Cho, J.H.; Choi, J.W.; Lee, J.I.; Suh, Y.L.; Ku, B.M.; Eum, H.H.; et al. Single-cell RNA sequencing demonstrates the molecular and cellular reprogramming of metastatic lung adenocarcinoma. Nat. Commun. 2020, 11, 2285. [CrossRef]

46. Wu, F.; Fan, J.; He, Y.; Xiong, A.; Yu, J.; Li, Y.; Zhang, Y.; Zhao, W.; Zhou, F.; Li, W.; et al. Single-cell profiling of tumor heterogeneity and the microenvironment in advanced non-small cell lung cancer. Nat. Commun. 2021, 12, 2540. [CrossRef]

47. Wang, Y.; Waters, J.; Leung, M.L.; Unruh, A.; Roh, W.; Shi, X.; Chen, K.; Scheet, P.; Vattathil, S.; Liang, H.; et al. Clonal evolution in breast cancer revealed by single nucleus genome sequencing. Nature 2014, 512, 155-160. [CrossRef] [PubMed]

48. Kim, C.; Gao, R.; Sei, E.; Brandt, R.; Hartman, J.; Hatschek, T.; Crosetto, N.; Foukakis, T.; Navin, N.E. Chemoresistance Evolution in Triple-Negative Breast Cancer Delineated by Single-Cell Sequencing. Cell 2018, 173, 879-893.e813. [CrossRef]

49. Lee, H.O.; Hong, Y.; Etlioglu, H.E.; Cho, Y.B.; Pomella, V.; Van den Bosch, B.; Vanhecke, J.; Verbandt, S.; Hong, H.; Min, J.W.; et al. Lineage-dependent gene expression programs influence the immune landscape of colorectal cancer. Nat. Genet. 2020, 52, 594-603. [CrossRef]

50. Izar, B.; Tirosh, I.; Stover, E.H.; Wakiro, I.; Cuoco, M.S.; Alter, I.; Rodman, C.; Leeson, R.; Su, M.J.; Shah, P.; et al. A single-cell landscape of high-grade serous ovarian cancer. Nat. Med. 2020, 26, 1271-1279. [CrossRef] [PubMed]

51. Neftel, C.; Laffy, J.; Filbin, M.G.; Hara, T.; Shore, M.E.; Rahme, G.J.; Richman, A.R.; Silverbush, D.; Shaw, M.L.; Hebert, C.M.; et al. An Integrative Model of Cellular States, Plasticity, and Genetics for Glioblastoma. Cell 2019, 178, 835-849.e821. [CrossRef]

52. Puram, S.V.; Tirosh, I.; Parikh, A.S.; Patel, A.P.; Yizhak, K.; Gillespie, S.; Rodman, C.; Luo, C.L.; Mroz, E.A.; Emerick, K.S.; et al. Single-Cell Transcriptomic Analysis of Primary and Metastatic Tumor Ecosystems in Head and Neck Cancer. Cell 2017, 171, 1611-1624.e1624. [CrossRef] [PubMed]

53. Chung, W.; Eum, H.H.; Lee, H.O.; Lee, K.M.; Lee, H.B.; Kim, K.T.; Ryu, H.S.; Kim, S.; Lee, J.E.; Park, Y.H.; et al. Single-cell RNA-seq enables comprehensive tumour and immune cell profiling in primary breast cancer. Nat. Commun. 2017, 8, 15081. [CrossRef] [PubMed]

54. Li, H.; Courtois, E.T.; Sengupta, D.; Tan, Y.; Chen, K.H.; Goh, J.J.L.; Kong, S.L.; Chua, C.; Hon, L.K.; Tan, W.S.; et al. Reference component analysis of single-cell transcriptomes elucidates cellular heterogeneity in human colorectal tumors. Nat. Genet. 2017, 49, 708-718. [CrossRef] [PubMed]

55. Lee, H.W.; Chung, W.; Lee, H.O.; Jeong, D.E.; Jo, A.; Lim, J.E.; Hong, J.H.; Nam, D.H.; Jeong, B.C.; Park, S.H.; et al. Single-cell RNA sequencing reveals the tumor microenvironment and facilitates strategic choices to circumvent treatment failure in a chemorefractory bladder cancer patient. Genome Med. 2020, 12, 47. [CrossRef]

56. Yarchoan, M.; Albacker, L.A.; Hopkins, A.C.; Montesion, M.; Murugesan, K.; Vithayathil, T.T.; Zaidi, N.; Azad, N.S.; Laheru, D.A.; Frampton, G.M.; et al. PD-L1 expression and tumor mutational burden are independent biomarkers in most cancers. JCI Insight 2019, 4. [CrossRef]

57. Darvin, P.; Toor, S.M.; Sasidharan Nair, V.; Elkord, E. Immune checkpoint inhibitors: Recent progress and potential biomarkers. Exp. Mol. Med. 2018, 50,1-11. [CrossRef] [PubMed] 
58. Daud, A.I.; Loo, K.; Pauli, M.L.; Sanchez-Rodriguez, R.; Sandoval, P.M.; Taravati, K.; Tsai, K.; Nosrati, A.; Nardo, L.; Alvarado, M.D.; et al. Tumor immune profiling predicts response to anti-PD-1 therapy in human melanoma. J. Clin. Investig. 2016, 126, 3447-3452. [CrossRef] [PubMed]

59. Huang, A.C.; Postow, M.A.; Orlowski, R.J.; Mick, R.; Bengsch, B.; Manne, S.; Xu, W.; Harmon, S.; Giles, J.R.; Wenz, B.; et al. T-cell invigoration to tumour burden ratio associated with anti-PD-1 response. Nature 2017, 545, 60-65. [CrossRef] [PubMed]

60. Kamphorst, A.O.; Pillai, R.N.; Yang, S.; Nasti, T.H.; Akondy, R.S.; Wieland, A.; Sica, G.L.; Yu, K.; Koenig, L.; Patel, N.T.; et al. Proliferation of PD-1+CD8 T cells in peripheral blood after PD-1-targeted therapy in lung cancer patients. Proc. Natl. Acad. Sci. USA 2017, 114, 4993-4998. [CrossRef] [PubMed]

61. Wei, S.C.; Levine, J.H.; Cogdill, A.P.; Zhao, Y.; Anang, N.A.S.; Andrews, M.C.; Sharma, P.; Wang, J.; Wargo, J.A.; Pe'er, D.; et al. Distinct Cellular Mechanisms Underlie Anti-CTLA-4 and Anti-PD-1 Checkpoint Blockade. Cell 2017, 170, 1120-1133.e1117. [CrossRef] [PubMed]

62. Thommen, D.S.; Koelzer, V.H.; Herzig, P.; Roller, A.; Trefny, M.; Dimeloe, S.; Kiialainen, A.; Hanhart, J.; Schill, C.; Hess, C.; et al. A transcriptionally and functionally distinct PD-1(+) CD8(+) T cell pool with predictive potential in non-small-cell lung cancer treated with PD-1 blockade. Nat. Med. 2018, 24, 994-1004. [CrossRef]

63. Sade-Feldman, M.; Yizhak, K.; Bjorgaard, S.L.; Ray, J.P.; de Boer, C.G.; Jenkins, R.W.; Lieb, D.J.; Chen, J.H.; Frederick, D.T.; Barzily-Rokni, M.; et al. Defining T Cell States Associated with Response to Checkpoint Immunotherapy in Melanoma. Cell 2019, 176, 404. [CrossRef] [PubMed]

64. Gide, T.N.; Quek, C.; Menzies, A.M.; Tasker, A.T.; Shang, P.; Holst, J.; Madore, J.; Lim, S.Y.; Velickovic, R.; Wongchenko, M.; et al. Distinct Immune Cell Populations Define Response to Anti-PD-1 Monotherapy and Anti-PD-1/Anti-CTLA-4 Combined Therapy. Cancer Cell 2019, 35, 238-255.e236. [CrossRef]

65. Huang, A.C.; Orlowski, R.J.; Xu, X.; Mick, R.; George, S.M.; Yan, P.K.; Manne, S.; Kraya, A.A.; Wubbenhorst, B.; Dorfman, L.; et al. A single dose of neoadjuvant PD-1 blockade predicts clinical outcomes in resectable melanoma. Nat. Med. 2019, 25, 454-461. [CrossRef]

66. Litchfield, K.; Reading, J.L.; Puttick, C.; Thakkar, K.; Abbosh, C.; Bentham, R.; Watkins, T.B.K.; Rosenthal, R.; Biswas, D.; Rowan, A.; et al. Meta-analysis of tumor- and T cell-intrinsic mechanisms of sensitization to checkpoint inhibition. Cell 2021, 184, 596-614.e514. [CrossRef]

67. Krishna, C.; DiNatale, R.G.; Kuo, F.; Srivastava, R.M.; Vuong, L.; Chowell, D.; Gupta, S.; Vanderbilt, C.; Purohit, T.A.; Liu, M.; et al. Single-cell sequencing links multiregional immune landscapes and tissue-resident $\mathrm{T}$ cells in ccRCC to tumor topology and therapy efficacy. Cancer Cell 2021, 39, 662-677.e666. [CrossRef] [PubMed]

68. Kwon, M.; An, M.; Klempner, S.J.; Lee, H.; Kim, K.M.; Sa, J.K.; Cho, H.J.; Hong, J.Y.; Lee, T.; Min, Y.W.; et al. Determinants of Response and Intrinsic Resistance to PD-1 Blockade in Microsatellite Instability-High Gastric Cancer. Cancer Discov. 2021. [CrossRef] [PubMed]

69. Sade-Feldman, M.; Yizhak, K.; Bjorgaard, S.L.; Ray, J.P.; de Boer, C.G.; Jenkins, R.W.; Lieb, D.J.; Chen, J.H.; Frederick, D.T.; Barzily-Rokni, M.; et al. Defining T Cell States Associated with Response to Checkpoint Immunotherapy in Melanoma. Cell 2018, 175, 998-1013.e1020. [CrossRef]

70. Jerby-Arnon, L.; Shah, P.; Cuoco, M.S.; Rodman, C.; Su, M.J.; Melms, J.C.; Leeson, R.; Kanodia, A.; Mei, S.; Lin, J.R.; et al. A Cancer Cell Program Promotes T Cell Exclusion and Resistance to Checkpoint Blockade. Cell 2018, 175, 984-997.e924. [CrossRef] [PubMed]

71. Satpathy, A.T.; Granja, J.M.; Yost, K.E.; Qi, Y.; Meschi, F.; McDermott, G.P.; Olsen, B.N.; Mumbach, M.R.; Pierce, S.E.; Corces, M.R.; et al. Massively parallel single-cell chromatin landscapes of human immune cell development and intratumoral $\mathrm{T}$ cell exhaustion. Nat. Biotechnol. 2019, 37, 925-936. [CrossRef]

72. Yost, K.E.; Satpathy, A.T.; Wells, D.K.; Qi, Y.; Wang, C.; Kageyama, R.; McNamara, K.L.; Granja, J.M.; Sarin, K.Y.; Brown, R.A.; et al. Clonal replacement of tumor-specific T cells following PD-1 blockade. Nat. Med. 2019, 25, 1251-1259. [CrossRef]

73. Lee, J.; Hyeon, D.Y.; Hwang, D. Single-cell multiomics: Technologies and data analysis methods. Exp. Mol. Med. 2020, 52, 1428-1442. [CrossRef] [PubMed]

74. Macaulay, I.C.; Haerty, W.; Kumar, P.; Li, Y.I.; Hu, T.X.; Teng, M.J.; Goolam, M.; Saurat, N.; Coupland, P.; Shirley, L.M.; et al. G\&T-seq: Parallel sequencing of single-cell genomes and transcriptomes. Nat. Methods 2015, 12, 519-522. [CrossRef] [PubMed]

75. Bian, S.; Hou, Y.; Zhou, X.; Li, X.; Yong, J.; Wang, Y.; Wang, W.; Yan, J.; Hu, B.; Guo, H.; et al. Single-cell multiomics sequencing and analyses of human colorectal cancer. Science 2018, 362, 1060-1063. [CrossRef]

76. Gao, R.; Bai, S.; Henderson, Y.C.; Lin, Y.; Schalck, A.; Yan, Y.; Kumar, T.; Hu, M.; Sei, E.; Davis, A.; et al. Delineating copy number and clonal substructure in human tumors from single-cell transcriptomes. Nat. Biotechnol. 2021, 39, 599-608. [CrossRef] [PubMed]

77. Serin Harmanci, A.; Harmanci, A.O.; Zhou, X. CaSpER identifies and visualizes CNV events by integrative analysis of single-cell or bulk RNA-sequencing data. Nat. Commun. 2020, 11, 89. [CrossRef] [PubMed]

78. Fan, J.; Lee, H.O.; Lee, S.; Ryu, D.E.; Lee, S.; Xue, C.; Kim, S.J.; Kim, K.; Barkas, N.; Park, P.J.; et al. Linking transcriptional and genetic tumor heterogeneity through allele analysis of single-cell RNA-seq data. Genome Res. 2018, 28, 1217-1227. [CrossRef] [PubMed]

79. Couturier, C.P.; Ayyadhury, S.; Le, P.U.; Nadaf, J.; Monlong, J.; Riva, G.; Allache, R.; Baig, S.; Yan, X.; Bourgey, M.; et al. Single-cell RNA-seq reveals that glioblastoma recapitulates a normal neurodevelopmental hierarchy. Nat. Commun. 2020, 11, 3406. [CrossRef] 
80. Muller, S.; Cho, A.; Liu, S.J.; Lim, D.A.; Diaz, A. CONICS integrates scRNA-seq with DNA sequencing to map gene expression to tumor sub-clones. Bioinformatics 2018, 34, 3217-3219. [CrossRef]

81. Nam, A.S.; Kim, K.T.; Chaligne, R.; Izzo, F.; Ang, C.; Taylor, J.; Myers, R.M.; Abu-Zeinah, G.; Brand, R.; Omans, N.D.; et al. Somatic mutations and cell identity linked by Genotyping of Transcriptomes. Nature 2019, 571, 355-360. [CrossRef] [PubMed]

82. Vu, T.N.; Nguyen, H.N.; Calza, S.; Kalari, K.R.; Wang, L.; Pawitan, Y. Cell-level somatic mutation detection from single-cell RNA sequencing. Bioinformatics 2019, 35, 4679-4687. [CrossRef]

83. Zhou, Z.; Xu, B.; Minn, A.; Zhang, N.R. DENDRO: Genetic heterogeneity profiling and subclone detection by single-cell RNA sequencing. Genome Biol. 2020, 21, 10. [CrossRef]

84. Peterson, V.M.; Zhang, K.X.; Kumar, N.; Wong, J.; Li, L.; Wilson, D.C.; Moore, R.; McClanahan, T.K.; Sadekova, S.; Klappenbach, J.A. Multiplexed quantification of proteins and transcripts in single cells. Nat. Biotechnol. 2017, 35, 936-939. [CrossRef] [PubMed]

85. Stoeckius, M.; Hafemeister, C.; Stephenson, W.; Houck-Loomis, B.; Chattopadhyay, P.K.; Swerdlow, H.; Satija, R.; Smibert, P. Simultaneous epitope and transcriptome measurement in single cells. Nat. Methods 2017, 14, 865-868. [CrossRef] [PubMed]

86. Hao, Y.; Hao, S.; Andersen-Nissen, E.; Mauck, W.M., 3rd; Zheng, S.; Butler, A.; Lee, M.J.; Wilk, A.J.; Darby, C.; Zager, M.; et al. Integrated analysis of multimodal single-cell data. Cell 2021, 184, 3573-3587.e3529. [CrossRef] [PubMed]

87. Mimitou, E.P.; Lareau, C.A.; Chen, K.Y.; Zorzetto-Fernandes, A.L.; Hao, Y.; Takeshima, Y.; Luo, W.; Huang, T.S.; Yeung, B.Z.; Papalexi, E.; et al. Scalable, multimodal profiling of chromatin accessibility, gene expression and protein levels in single cells. Nat. Biotechnol. 2021. [CrossRef] [PubMed]

88. Dixit, A.; Parnas, O.; Li, B.; Chen, J.; Fulco, C.P.; Jerby-Arnon, L.; Marjanovic, N.D.; Dionne, D.; Burks, T.; Raychowdhury, R.; et al. Perturb-Seq: Dissecting Molecular Circuits with Scalable Single-Cell RNA Profiling of Pooled Genetic Screens. Cell 2016, 167, 1853-1866.e1817. [CrossRef] [PubMed]

89. Papalexi, E.; Mimitou, E.P.; Butler, A.W.; Foster, S.; Bracken, B.; Mauck, W.M., 3rd; Wessels, H.H.; Hao, Y.; Yeung, B.Z.; Smibert, P.; et al. Characterizing the molecular regulation of inhibitory immune checkpoints with multimodal single-cell screens. Nat. Genet. 2021, 53, 322-331. [CrossRef] [PubMed]

90. Nagle, M.P.; Tam, G.S.; Maltz, E.; Hemminger, Z.; Wollman, R. Bridging scales: From cell biology to physiology using in situ single-cell technologies. Cell Syst. 2021, 12, 388-400. [CrossRef] [PubMed]

91. Rozenblatt-Rosen, O.; Shin, J.W.; Rood, J.E.; Hupalowska, A.; Human Cell Atlas Standards and Technology Working Group; Regev, A.; Heyn, H. Building a high-quality Human Cell Atlas. Nat. Biotechnol. 2021, 39, 149-153. [CrossRef] [PubMed]

92. Savas, P.; Virassamy, B.; Ye, C.; Salim, A.; Mintoff, C.P.; Caramia, F.; Salgado, R.; Byrne, D.J.; Teo, Z.L.; Dushyanthen, S.; et al. Single-cell profiling of breast cancer T cells reveals a tissue-resident memory subset associated with improved prognosis. Nat. Med. 2018, 24, 986-993. [CrossRef] [PubMed]

93. Chen, Y.P.; Yin, J.H.; Li, W.F.; Li, H.J.; Chen, D.P.; Zhang, C.J.; Lv, J.W.; Wang, Y.Q.; Li, X.M.; Li, J.Y.; et al. Single-cell transcriptomics reveals regulators underlying immune cell diversity and immune subtypes associated with prognosis in nasopharyngeal carcinoma. Cell Res. 2020, 30, 1024-1042. [CrossRef]

94. Eum, H.H.; Kwon, M.; Ryu, D.; Jo, A.; Chung, W.; Kim, N.; Hong, Y.; Son, D.S.; Kim, S.T.; Lee, J.; et al. Tumor-promoting macrophages prevail in malignant ascites of advanced gastric cancer. Exp. Mol. Med. 2020, 52, 1976-1988. [CrossRef] [PubMed]

95. Newman, A.M.; Steen, C.B.; Liu, C.L.; Gentles, A.J.; Chaudhuri, A.A.; Scherer, F.; Khodadoust, M.S.; Esfahani, M.S.; Luca, B.A.; Steiner, D.; et al. Determining cell type abundance and expression from bulk tissues with digital cytometry. Nat. Biotechnol. 2019, 37, 773-782. [CrossRef] [PubMed]

96. Dong, R.; Yang, R.; Zhan, Y.; Lai, H.D.; Ye, C.J.; Yao, X.Y.; Luo, W.Q.; Cheng, X.M.; Miao, J.J.; Wang, J.F.; et al. Single-Cell Characterization of Malignant Phenotypes and Developmental Trajectories of Adrenal Neuroblastoma. Cancer Cell 2020, 38, 716-733.e716. [CrossRef]

97. Chen, Z.; Zhou, L.; Liu, L.; Hou, Y.; Xiong, M.; Yang, Y.; Hu, J.; Chen, K. Single-cell RNA sequencing highlights the role of inflammatory cancer-associated fibroblasts in bladder urothelial carcinoma. Nat. Commun. 2020, 11, 5077. [CrossRef] [PubMed]

98. Qi, Z.; Liu, Y.; Mints, M.; Mullins, R.; Sample, R.; Law, T.; Barrett, T.; Mazul, A.L.; Jackson, R.S.; Kang, S.Y.; et al. Single-Cell Deconvolution of Head and Neck Squamous Cell Carcinoma. Cancers 2021, 13, 1230. [CrossRef] [PubMed]

99. Bi, K.; He, M.X.; Bakouny, Z.; Kanodia, A.; Napolitano, S.; Wu, J.; Grimaldi, G.; Braun, D.A.; Cuoco, M.S.; Mayorga, A.; et al. Tumor and immune reprogramming during immunotherapy in advanced renal cell carcinoma. Cancer Cell 2021, 39, 649-661.e645. [CrossRef] [PubMed]

100. Avila Cobos, F.; Alquicira-Hernandez, J.; Powell, J.E.; Mestdagh, P.; De Preter, K. Benchmarking of cell type deconvolution pipelines for transcriptomics data. Nat. Commun. 2020, 11, 5650. [CrossRef] [PubMed]

101. Li, H.; van der Leun, A.M.; Yofe, I.; Lubling, Y.; Gelbard-Solodkin, D.; van Akkooi, A.C.J.; van den Braber, M.; Rozeman, E.A.; Haanen, J.; Blank, C.U.; et al. Dysfunctional CD8 T Cells Form a Proliferative, Dynamically Regulated Compartment within Human Melanoma. Cell 2020, 181, 747. [CrossRef]

102. Nirschl, C.J.; Suarez-Farinas, M.; Izar, B.; Prakadan, S.; Dannenfelser, R.; Tirosh, I.; Liu, Y.; Zhu, Q.; Devi, K.S.P.; Carroll, S.L.; et al. IFNgamma-Dependent Tissue-Immune Homeostasis Is Co-opted in the Tumor Microenvironment. Cell 2017, 170, 127-141.e115. [CrossRef]

103. Li, H.; van der Leun, A.M.; Yofe, I.; Lubling, Y.; Gelbard-Solodkin, D.; van Akkooi, A.C.J.; van den Braber, M.; Rozeman, E.A.; Haanen, J.; Blank, C.U.; et al. Dysfunctional CD8 T Cells Form a Proliferative, Dynamically Regulated Compartment within Human Melanoma. Cell 2019, 176, 775-789.e718. [CrossRef] 
104. Zhang, L.; Yu, X.; Zheng, L.; Zhang, Y.; Li, Y.; Fang, Q.; Gao, R.; Kang, B.; Zhang, Q.; Huang, J.Y.; et al. Lineage tracking reveals dynamic relationships of T cells in colorectal cancer. Nature 2018, 564, 268-272. [CrossRef]

105. Goldstein, L.D.; Chen, Y.J.; Wu, J.; Chaudhuri, S.; Hsiao, Y.C.; Schneider, K.; Hoi, K.H.; Lin, Z.; Guerrero, S.; Jaiswal, B.S.; et al. Massively parallel single-cell B-cell receptor sequencing enables rapid discovery of diverse antigen-reactive antibodies. Commun. Biol. 2019, 2, 304. [CrossRef] [PubMed]

106. Li, F.; Luo, M.; Zhou, W.; Li, J.; Jin, X.; Xu, Z.; Juan, L.; Zhang, Z.; Li, Y.; Liu, R.; et al. Single cell RNA and immune repertoire profiling of COVID-19 patients reveal novel neutralizing antibody. Protein Cell 2020. [CrossRef] [PubMed]

107. Browaeys, R.; Saelens, W.; Saeys, Y. NicheNet: Modeling intercellular communication by linking ligands to target genes. Nat. Methods 2020, 17, 159-162. [CrossRef] [PubMed]

108. Efremova, M.; Vento-Tormo, M.; Teichmann, S.A.; Vento-Tormo, R. CellPhoneDB: Inferring cell-cell communication from combined expression of multi-subunit ligand-receptor complexes. Nat. Protoc. 2020, 15, 1484-1506. [CrossRef] [PubMed] 